DOI: $10.22616 /$ REEP.2019.014

\title{
Modern Educational Domain: Cross-cultural Issues in Teaching Foreign Languages
}

\author{
Natalia V. Rezepova ${ }^{1} \mathrm{PhD}$.; Liya D. Torosyan ${ }^{2} \mathrm{PhD}$; Katerina A. Stepanenko ${ }^{3} \mathrm{PhD}$ \\ Plekhanov Russian University of Economics, Russia \\ natalia0309@list.ru1; liya-torosyan@yandex.ru²; valentinova_kate@mail.ru³
}

\begin{abstract}
: the topicality of the research stems from diverse linguistic and cultural fusion due to increasingly growing number of people who are able to speak two or more languages globally. The research goal is to reveal the level of cross-cultural competence of the university teaching staff and, correspondingly, elaborate a new proposal of a selection procedure for the applicants on the teaching positions simultaneously stating that being natural bilingual or multilingual teacher can be far more beneficial within modern educational domain. To visualize possible prospects and advantages of cross-cultural flexibility of natural bilingual and multilingual teachers within modern educational domain a special study was carried out. The research incorporated two clusters of the participants: the students (210) and the teaching staff (50) at Plekhanov Russian University of Economics. To achieve the aim of the study, the researchers' team used a set of methods: 1) theoretical analysis to verify practical findings; 2) monitoring of the courses attendance to check a level of students' engagement; 3 ) word association test to track a difference between various patterns of teachers' cross-cultural flexibility; 4) elaboration of a new selection procedure stages for the teaching staff (foreign language positions). The authors of the research paper put forward a hypothesis that natural bilingual or multilingual teachers are far more prone to demonstrate cross-cultural flexibility in a classroom, as they are highly disposed to demonstrate shiftability, adaptability, responsiveness and sensitivity within the interaction framework implying cultural and linguistic diversity of the students. The results obtained demonstrated a high students' perceptiveness to a teacher's ability to orientate in a new cultural environment, to facilitate a teacher-student or student-student communication by easily adapting to a different culture; diversification of values, beliefs, norms and standards. The researchers elaborated a new proposal of a selection procedure for the applicants on the teaching positions (foreign languages) at the University, which resulted in its final form at the assessment and evaluative stage of the study and has been successfully implemented so far in HR university practices. This proposal comprises a sequence of obligatory stages and exposes a preference towards natural bilingual or multilingual teachers with convincing degree of cross-cultural flexibility.
\end{abstract}

Keywords: cross-cultural flexibility in classroom, bilingualism, multilingualism, university education.

\section{Introduction}

The historic mission of education is multifaceted and implies three main milestones such as training, upbringing and development of an individual. Essentially the role of education comes to personal evolution from transmission of ethical and cultural values to preparedness for performing various social roles. It should be noted that the mission of education differs dramatically from how it was delivered two decades ago. Nowadays it reflects concepts adjusted to the uttermost to the present-day cross-cultural educational landscape which centres around two liaisons: an agent (a teacher) and a beneficiary (a student).

Their interaction and integration into the educational domain play the core role in the learning process modelling. This article focuses on the teacher, his impact on training, upbringing and development of an individual (student) within the environment in which classroom represents a body with coexisting cultures, values and beliefs.

There have been a lot of debates among educators on the teacher's role, profile and influence on the effectiveness of the learning process (Barry, 2010; Markova, 1996; Navickiene, Urneziene, 2017; Zimnyaya, 2000). It should be highlighted that A.K. Markova (1996) made an attempt to represent features of a teacher which are divided into objective and subjective ones. Objective features include educational background and field-specific knowledge. Subjective features embrace knowhow skills, personal experience and ability to convey and transmit possessed knowledge. Personal features implicate charisma, psychological peculiarities and moral attitudes to those involved in the educational process.

A.K. Markova (1996) defined a teacher as a subject of educational activity identifying three interdependent components such as teaching activities, pedagogical communication and personality. In the framework of 
the model "activities-communication-personality" several authors highlighted a set of pedagogical abilities determining the efficiency of learning process: goal-setting, critical thinking, self-analysis, sensitivity, professional focus (Barry, 2010; Creasy, 2015; Danilane, Lubkina, Lubkins, 2007; Pridane, 2018, 322).

Despite the fact there have been conducted a lot of research studies dedicated to the role and influence of a teacher (Kniel, 2009; Lasauskiene, Bagdonaviciute, 2018; Markova, 1996; Zimnyaya, 2000) nevertheless we should acknowledge that more attention should be paid to the cultural component. Today the majority of universities are striving for large international students' intake as it increases the indexes of universities' ranking in different systems such as QS World University, Round University Rankings, etc. Unfortunately, in many cases the institutions of higher education haven't worked out yet any mechanisms to mediate between host and invited or joined parties. Among the main arising issues encountered by arriving students are challenges directly connected with cultural adaptation and attempt to find balance between dominant (host party's) culture and submissive (their own) culture. On the one hand, international students have to blend into a new habitat, on the other hand, they display strong willingness to preserve their authenticity and not to be exposed to any kind of cultural transformation or what is even worse cultural isolation.

Cross-cultural education scholars all argued that pedagogy must be «culturally responsive» (Gay, 2000, 2001; Guido, 2017; Ladson-Billings, 1995a, 1995b; Nilsson, Kong, Hubert, 2016) and «culturally inclusive» (Baptiste, Key, 1996; Key, 1996; Designing Culturally Inclusive..., 2018) addressing globalizing world challenges and hence teachers have to demonstrate a disposition to become culturally responsive (Samuels, 2018), to develop relevant abilities which are to be gained not abstractly or uncoupled from cross-cultural communication but through active engagement into it.

It's beyond dispute that being culturally flexible or responsive is not merely a matter of implementing relevant teaching techniques and methods but «it is primarily a matter of tailoring instruction to incorporate assumed traits or customs of particular cultural groups» (Villegas, Lucas, 2002, 27).

All these tenets entitle the authors to add to the list of pedagogical abilities the new one "cross-cultural flexibility" which is to serve to mitigate cultural differences and bridge cultural gaps (Figure 1).

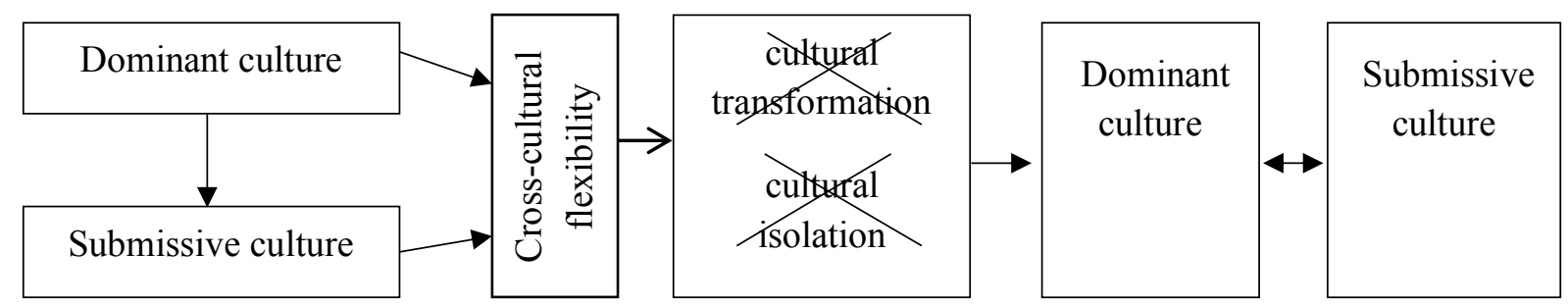

Figure 1. Cultures' correlation in a classroom.

The authors determine cross-cultural flexibility as a teacher's ability:

- «to orientate in a new cultural environment, to facilitate a teacher-student or student-student communication by easily adapting to a different culture» (Rezepova et al., 2018, 114);

- «to orientate in a new cross-cultural environment, to select appropriate teaching techniques and methods to provide effective cross-cultural communication through group learning and peer tutoring; to eliminate any outpouring of cultural transformation and isolation» (Gordeeva, Stepanenko, Torosyan, 2018, 766).

Cross-cultural flexibility represents an assembly of abilities of a teacher to respond correspondently to the beneficiaries' high aspirations and requirements in terms of cultural interblending and interfusion. All these abilities are unpacked below which is illustrated in Figure 2.

To facilitate the adaptation of international students with diverse racial, ethnic, cultural and language background an educator is to demonstrate abovementioned abilities to successfully manage crosscultural classroom. All these abilities pieced together give a revealing insight into the teacher's crosscultural competence which is defined as the acquisition of culture-specific knacks needed «to (a) function effectively within a new cultural context and/or (b) interact effectively with people from different cultural backgrounds» (Wilson, Ward, Fischer, 2013, 900). 


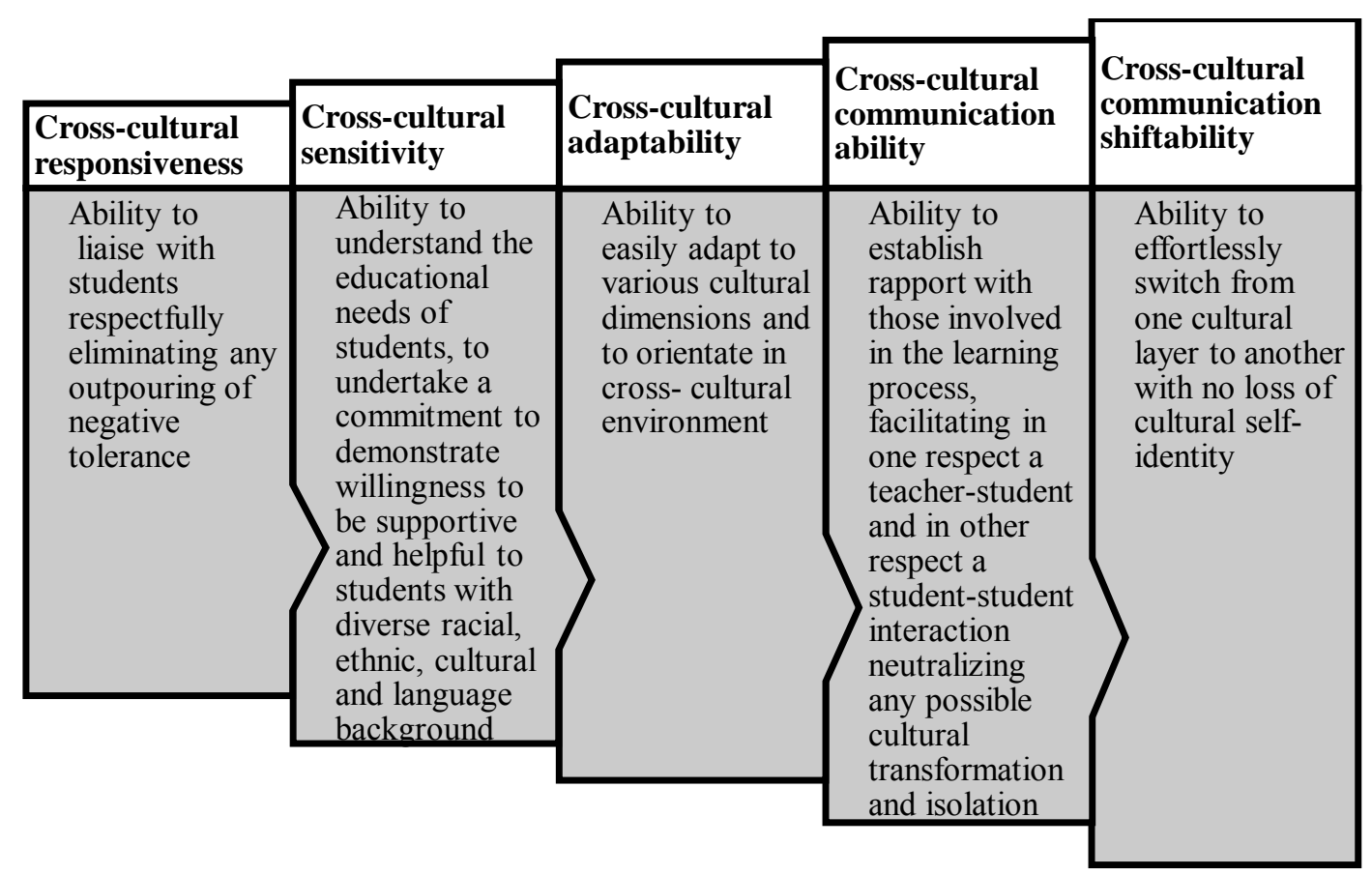

Figure 2. Assembly of abilities.

All these specify the aim of the study which is to reveal the level of cross-cultural competence of the university teaching staff and, correspondingly, put forward a new proposal of a selection procedure for the applicants on the teaching positions.

\section{Methodology}

Modern university students tend towards self-centred positioning and claim to be able to extract all subject-matter information, there is a crucial need to pose a challenge to get them interested. This very fact highlights an irrefutable issue on a new frame of teacher's competencies that should meet and even exceed divergent needs of the university youth fostering them to imply their background knowledge and skills in a beneficial way.

The authors of the research paper put forward a hypothesis that natural bilingual or multilingual teachers are far more prone to demonstrate cross-cultural flexibility in a classroom in comparison to artificial bilingual or multilingual ones, as these teachers are highly disposed to demonstrate shiftability, adaptability, responsiveness and sensitivity within the interaction framework implying cultural and linguistic diversity of the students.

Participants. The research involved two clusters of the participants. The firs cluster was represented by the students (210 students in general: 105 first year students and 105 third year students at C1 English level at Plekhanov Russian University of Economics). The second cluster was represented by the teaching staff (50 teachers) of Chair of Foreign Languages \#2 and Chair of Foreign Languages \#3 at Plekhanov Russian University of Economics.

The students' cluster outline: 106 students recognized themselves as being artificial bilinguals (with consecutive acquisition of a foreign language), 66 students recognized themselves as being natural bilinguals but artificial multilinguals (with simultaneous acquisition of first two languages and consecutive acquisition of a foreign language), and 38 students recognized themselves as being natural multilinguals (with simultaneous acquisition of first three languages and consecutive acquisition of a foreign language).

The teachers' cluster outline: 25 teachers identified themselves as being artificial bilinguals or multilinguals (with consecutive acquisition of a foreign language), 15 teachers identified themselves as being natural bilinguals but artificial multilinguals (with simultaneous acquisition of first two languages and consecutive acquisition of a foreign language), and 10 teachers identified themselves as being natural multilinguals (with simultaneous acquisition of first three languages and consecutive acquisition of a foreign language). 
The participants were thoroughly informed about the purpose of the research and voluntarily took part in it.

Methods. To achieve the aim of the study, the researchers' team used a fusion of methods:

1) theoretical analysis to back up practical findings;

2) monitoring of the courses attendance to check a level of students' engagement;

3) word association test to track a difference between various patterns of teachers' cross-cultural flexibility;

4) elaboration of a new selection procedure stages.

Procedure. The research incorporates three stages: preliminary stage, observation stage, and assessment and evaluative stage. At the preliminary stage the research team was reflecting on the composition of the study participants, its methods and subsequent stages.

The observation stage lasted from November 1, 2017 to November 1, 2018. During this pivotal stage the researchers' role was to offer the students to attend five extracurricular courses in English. The courses structure was compiled in the way to interlace meta-subject areas to boost students' soft skills and their involvement into the process.

Five courses were conducted by 25 teachers ( 5 teachers for each course), who are artificial bilinguals or multilinguals. The same five courses were conducted by the 25 teachers ( 5 teachers for each course), who are natural bilinguals or artificial multilinguals. Each course lasted 2 months and they were centered around extensive issues:

\section{Course 1: Working Abroad: Challenges and Benefits}

Course 2: Multicultural Business Environment

Course 3: International Businesses: Advantages and Disadvantages

Course 4: Multilinguism as a Must for Doing Business

Course 5: Shifts in Business Vocabulary

A research participant had to visit all the five courses having an option to move after a course completion from the cluster of teachers who are artificial bilinguals or multilinguals to the cluster of teachers who are natural bilinguals or multilinguals. Assessment and evaluative stage coincided with the last month of the observation stage and focused on the causal study in attempts to prove a cause-and-effect relationship of the initial hypothesis and empirical results.

\section{Results and Discussion}

The nature of cross-cultural flexibility prescribes certain educational principles to be followed in order to successfully handle a cross-cultural classroom.

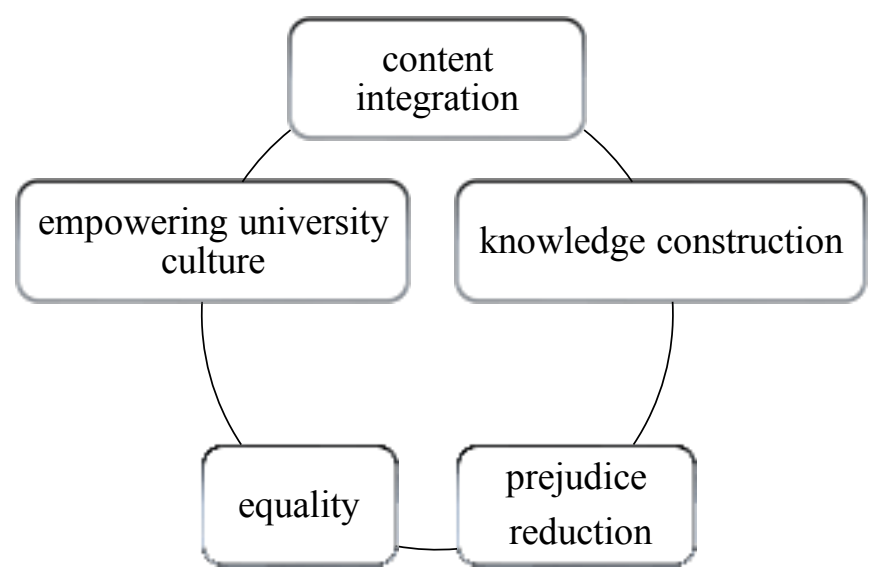

Figure 3. Core educational principles as the basis of cross-cultural flexibility.

These principles can be characterized in the following way (Figure 3):

- content integration suggests culturally relevant information and patterns conveyance and transmission;

- knowledge construction implies learning material cast and delivery avoiding any personal biases and judgements; 
- prejudice reduction involves instilling tolerance for cultural diversity;

- equality embraces equal opportunities for everyone disregarding their race, ethnicity, culture and language;

- empowering university culture implicates full compliance with the guidelines of equality and diversity (Banks, Banks, 2004; Banks et al., 2001; Key, 1996).

Undoubtedly, cross-cultural flexibility is a kind of ability enabling a teacher to absorb new cultural contexts which are alien to their mindset, to adjust their own teaching methods, techniques to the given cross-cultural environment. To manage to create an atmosphere in which students with various cultural background could feel secured once their differences are accepted or even shared it is vital to veer off the beaten track and bring new educational patterns into cross-cultural classroom. Traditional educators operate within the boundaries of one culture mentality which heavily impacts the system of beliefs, values and frame of reference. However, cross-cultural community requires rethinking of the existing educational paradigm and introducing the one better tailored to the culturally diverse student cohorts.

To effectively manage cross-cultural classroom, it is essential to identify major differences between traditional classroom and cross-cultural one. Here are the main seven parameters which seem to be critical for learning process guidance (Table 1).

Table 1

Traditional classroom versus cross-cultural one

\begin{tabular}{|l|l|l|}
\hline \multicolumn{1}{|c|}{ Parameters } & \multicolumn{1}{c|}{ Traditional } & \multicolumn{1}{c|}{ Cross-cultural } \\
\hline Culture involvement magnitude & Low & High \\
\hline Competition & Individual & Inter-group \\
\hline Class climate & Controlled & Collaborative \\
\hline $\begin{array}{l}\text { Teacher's engagement degree in the } \\
\text { educational process }\end{array}$ & High & Low \\
\hline Teacher's role & Teacher tells & Teacher guides \\
\hline Learning material differentiation & Age and ability customized & Age/ability and culture customized \\
\hline Study mode & Individual & Group \\
\hline
\end{tabular}

These beneficial peculiarities of a cross-cultural classroom are profoundly underpinned by an analysis of the courses attendees' distribution (Figure 4). If at the very beginning of the courses they were equally subdivided into two pools (105 and 105 correspondingly), then immediately after the first course completion there is a hard evidence towards interaction within the cluster guided by natural bilingual and multilingual teachers.

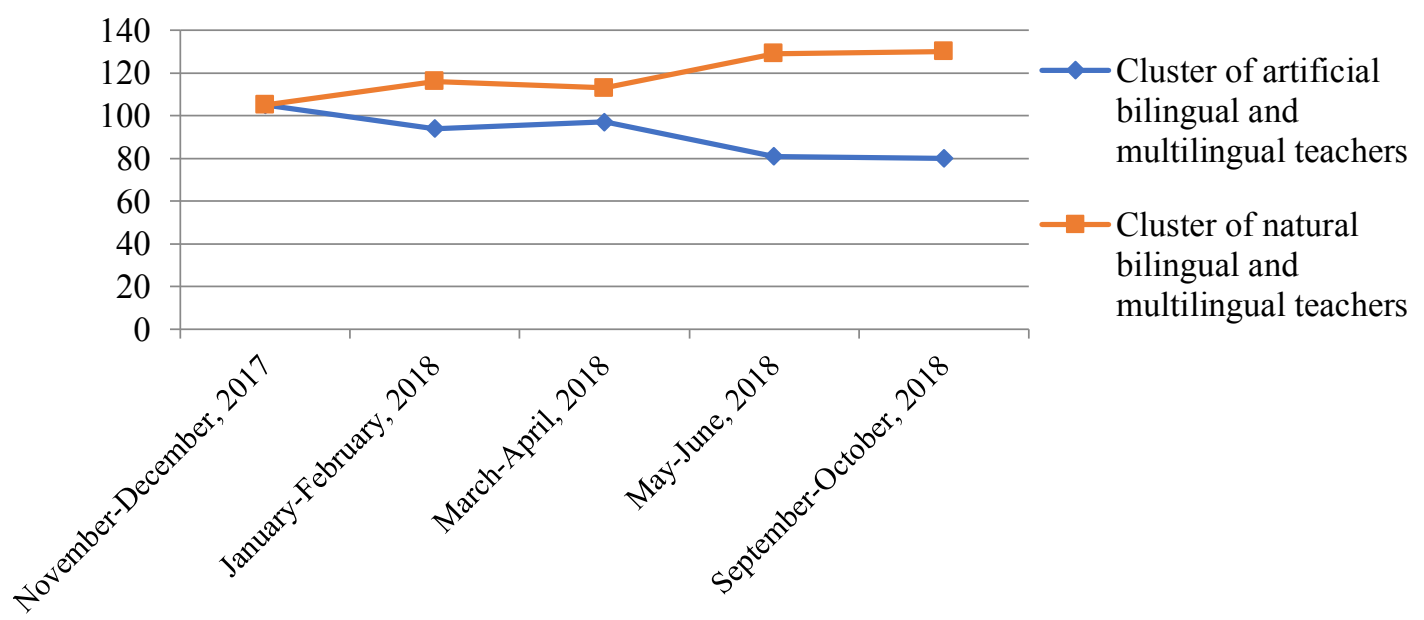

Figure 4. A Distribution of the Courses Attendees.

Such an evident preference might be explained by a teacher's ability to orientate in a new cultural environment, to facilitate a teacher-student or student-student communication by easily adapting to a different culture; diversification of values, beliefs, norms and standards which is a strategy applied by 
a teacher to selectively use those values, beliefs, norms and standards which are appropriate for the given communicative situation. Reflecting on the results of the association word test on cross-cultural flexibility of the teaching staff it is feasible to obtain an abundant proof of the researchers' hypothesis which implies in the fact that natural bilingual or multilingual teachers are far more prone to demonstrate cross-cultural flexibility in a classroom in comparison to artificial bilingual or multilingual ones.

Sufficiency pattern (Figure 5) clearly demonstrates that the core elements of the concept signal about teacher proficiency in "bridging languages" while making implications in case of being asked to exemplify some phenomena in different languages, ability to demonstrate divergent and creative thinking via sensitively cultured techniques and methods, running classes in the conditions of cross-cultural communication environment effectively. Insufficiency Pattern (Figure 6) displays a shift of the core elements to peripheral ones which means that either the teacher's assignments didn't appropriately meet challenging students' expectations or the teacher was not quite good at selecting and adapting resources in a learning process, mismanaging to master lesson content in accordance with students' expectations.

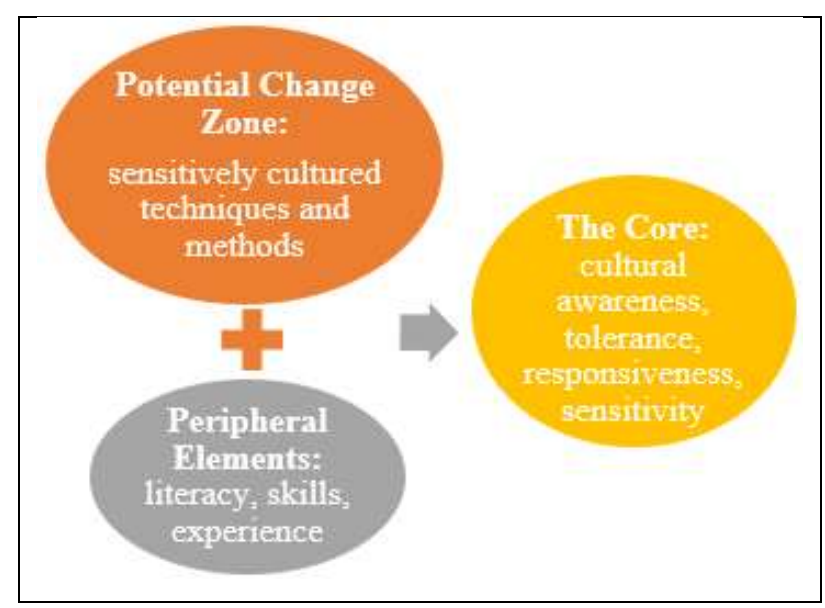

Figure 5. The elements forming the core and the periphery of associations about cross-cultural flexibility of a teacher (Sufficiency Pattern).

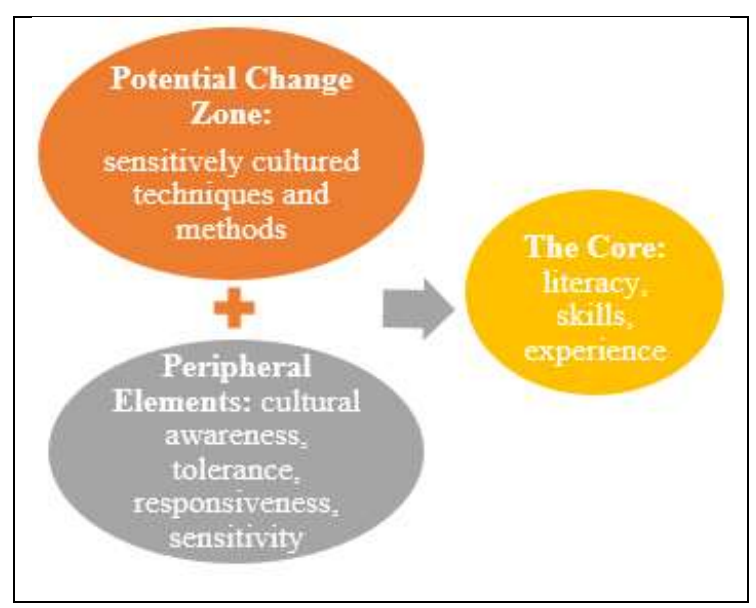

Figure 6. The elements forming the core and the periphery of associations about crosscultural flexibility of a teacher (Insufficiency Pattern).

Throughout the observation stage of the study the researchers had been elaborating a new proposal of a selection procedure for the applicants on the teaching positions (foreign languages) at Plekhanov Russian University of Economics which resulted in its final form at the assessment and evaluative stage of the study and has been successfully implemented so far (Figure 7). This proposal comprises a sequence of obligatory stages and exposes a preference towards natural bilingual or multilingual teachers with convincing degree of cross-cultural flexibility.

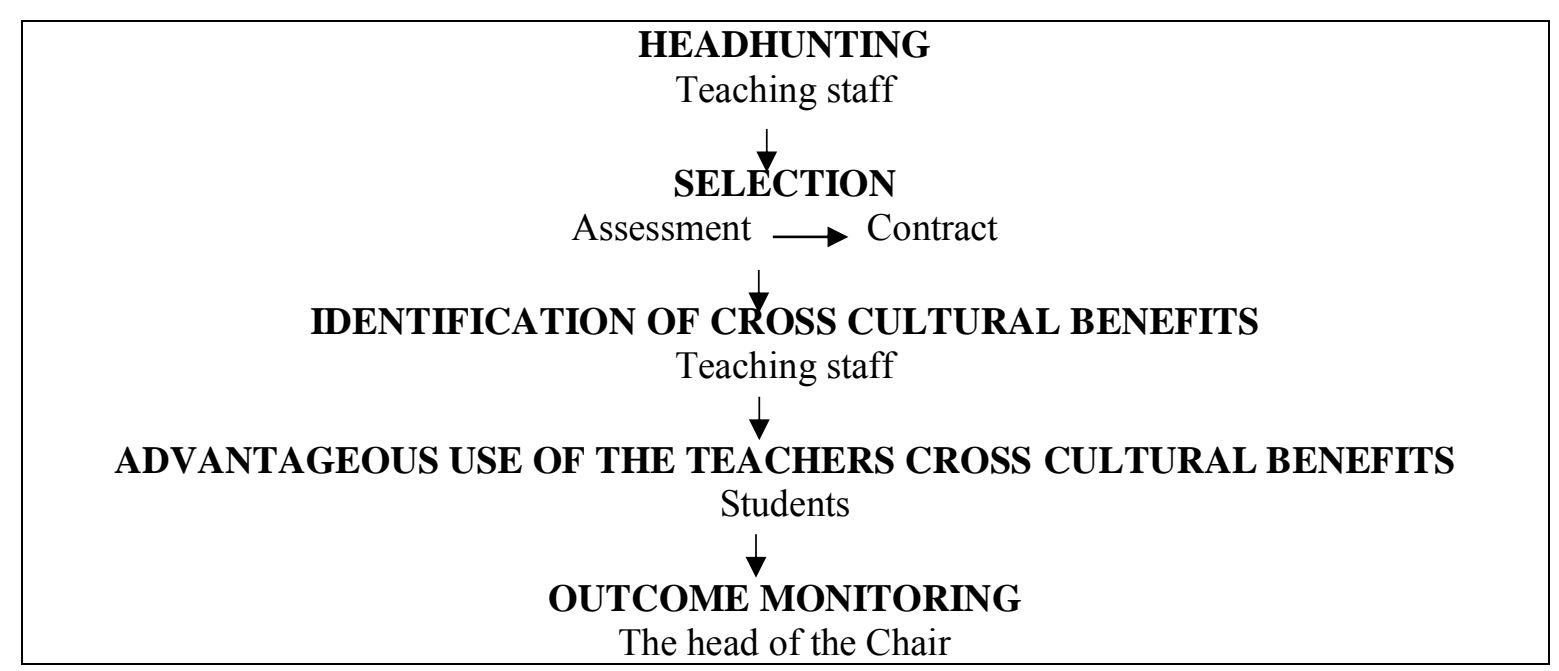

Figure 7. Selection Procedure for the Applicants. 


\section{Conclusions}

In the article the authors considered some issues related to cross-cultural education specifically teachers' profile in terms of intrinsic characteristics which contribute to effective cross-cultural classroom management.

Modern educational domain necessitates an educational paradigm shift which will be sensitive to cultural issues and challenges imposed by the present-day realia. Evidently, the role of a teacher can hardly be overestimated as a teacher is to demonstrate abilities to organize the learning process providing fair educational opportunities for all students disregarding their race, ethnic affiliation, culture and language. This means not to be merely blind to cultural differences but to foster tolerance and resilience with high cross-cultural involvement magnitude among all participants of the educational process. Thus, classroom environment becomes more tolerant and collaborative phasing out individual competition replacing it by inter-group one. There is also a focus shift from individual study mode to group one providing culturally relevant learning material.

Cross-cultural classrooms for now have only highly contributing benefits that effectively lower uncertainty avoidance - the degree of desire to avoid situations that may create a perceived threat for reasons of uncertainty or ambiguity; and increase intra-group collectivism - the degree of individual loyalty to small, including informal, groups. Such classrooms and type of interaction facilitate success of the group in generating new ideas, promote clarity of empowering tasks in the framework of the project implementation, sustain timeliness of tasks implementation in the course of the project, and enhance quality analysis of the information used.

Undeniably, an agent's (teacher's) implication shrinks to being supportive bringing to the front the importance of cross-cultural competence which creates additional benefits for teachers in terms of employability. A new proposal of a selection procedure for the applicants on the teaching positions (foreign languages) at Plekhanov Russian University of Economics has been devised. It incorporates a set of compulsory stages and proves validity of the authors' hypothesis regarding a certain preference towards natural bilingual or multilingual teachers with far more credible degree of cross-cultural flexibility in the classroom.

\section{Bibliography}

1. Banks J.A., Banks C.A.M. (Eds.). (2004). Handbook of Research on Multicultural Education. (2 $2^{\text {nd }}$ ed.). San Francisko, CA: Jossey-Bass.

2. Banks J.A., Cookson P., Gay G., Hawley W.D., Irvine J.J, Nieto S., Schofield J.W., Stephan W.G. (2001). Diversity Within Unity. Essential Principles for Teaching and Learning in a Multicultural Society. Seattle: Center for Multicultural Education, College of Education, University of Washington. Retrieved from https://education.uw.edu/sites/default/files/cme/docs/DiversityUnity.pdf

3. Baptiste H.P., Key S. (1996). Cultural Inclusion: Where does your program stand? The Science Teacher, 63 (2), 32-35.

4. Barry R.A. (2010). Teaching effectiveness and why it matters. USA: Marylhurst University and The Chalkboard project. Retrieved from https://chalkboardproject.org/sites/default/files/teachereffectiveness-and-why-it-matters.pdf

5. Creasy K. (2015). Defining Professionalism in Teacher Education Programs. Journal of Education and Social Policy, 2(2). Retrieved from https://files.eric.ed.gov/fulltext/ED563997.pdf

6. Danilane L., Lubkina V., Lubkins G. (2007). Implementation of Elements of Critical Thinking within Teaching Content. In A. Klein, D. Tangen, V.W. Thoresen (Eds.), The Consumer Citizenship Network conference proceedings, Building Bridges. Sofia: Forfatterne, 129-140. Retrieved from https://brage.bibsys.no/xmlui/bitstream/handle/11250/133645/opprapp02_2008.pdf

7. Designing Culturally Inclusive Classrooms: Teaching and Learning. (2018). Adelaide, Australia: Flinders University. Retrieved from http://www.flinders.edu.au/staff-developmentfiles/CDIP\%20documents/CDIP\%20Toolkit\%202017/Designing\%20Culturally\%20Inclusive\%20cla ssrooms.pdf

8. Gay G. (2000). Culturally Responsive Teaching: Theory, Research and Practice. New York: Teachers College Press.

9. Gay G. (2001). Curriculum Theory and Multicultural Education. In J. A. Banks, C. A. McGee Banks (Eds.), Handbook of research on multicultural education. San Francisco, CA: Jossey-Bass Publishers, 25-43. 
10. Key S.G. (1996). Diversity in Science Education. Research into Practice Science. Pearson Scott Foresman. Retrieved from http://assets.pearsonglobalschools.com/asset_mgr/current/20109/Diversity_in_Science_Education.pdf

11. Kniel S. (2009). Evaluating Intercultural Learning: Developing Key Skills through the International Dukenet Markstrat Programme. Kassel: Kassel University Press GmbH.

12. Gordeeva J.V., Stepanenko K.A., Torosyan L.D. (2018). Teaching in Cross-cultural Class- Benefits Built on Diversity. The Proceedings of the SGEM International Multidisciplinary Scientific Conference on Social Sciences and Arts, 5(3.4),763-770.

13. Guido M. (2017). 15 Culturally-Responsive Teaching Strategies. Retrieved from https://www.prodigygame.com/blog/culturally-responsive-teaching/

14. Ladson-Billings G. (1995a). But That's Just Good Teaching! The Case for Culturally Relevant Pedagogy. Theory into Practice, 34(3), 159-165. Retrieved from https://nationalequityproject.files.wordpress.com/2012/03/ladson-billings_1995.pdf

15. Ladson-Billings G. (1995b). Toward a Theory of Culturally Relevant Pedagogy. American Educational Research Journal, 32(3), 465-491. Retrieved from http://mcreadinglist.pbworks.com/f/Ladson-Billings\%20\%281995\%29.pdf

16. Lasauskiene J., Bagdonaviciute J. (2018). Building Intercultural Competence through Different International Study Programs at University. In V. Dislere (Ed.), The Proceedings of the International Scientific Conference Rural Environment. Education. Personality (REEP), 11. Jelgava: LLU TF, 215222. Retrieved from http://llufb.llu.lv/conference/REEP/2018/Latvia_REEP_2018_proceedings_ISSN2255808X.pdf

17. Markova A.K. (1996). Psixologiya Professionalizmā (Psychology of Professionalism). Moskva: Mezhdunarodnyj gumanitarnyj fond «Znaniye». (in Russian)

18. Navickiene V., Urneziene E. (2017). The Concept of the Need for Teachers' Educational Competences in the Strategic Documents of Lithuanian Higher Education. In V. Dislere (Ed.), The Proceedings of the International Scientific Conference Rural Environment. Education. Personality (REEP), 10. Jelgava: LLU TF, 300-307. Retrieved from http://llufb.llu.lv/conference/REEP/2017/Latvia-Univ-Agricult-REEP-2017 proceedings.pdf

19. Nilsson N.L., Kong A., Hubert S. (2016). Navigating the Challenges of Becoming a Culturally Responsive Teacher: Supportive Networking May Be the Key. Australian Journal of Teacher Education, 41(8). Retrieved from https://ro.ecu.edu.au/cgi/viewcontent.cgi?article=3190\&context=ajte

20. Pridane A. (2018). Development of Learning and Feedback Giving Skills in Home Economics and Technologies Education. In V. Dislere (Ed.), The Proceedings of the International Scientific Conference Rural Environment. Education. Personality (REEP), 11. Jelgava: LLU TF, 321-327. Retrieved from http://lufb.1lu.lv/conference/REEP/2018/Latvia_REEP_2018_proceedings_ISSN2255808X.pdf

21. Rezepova N., Torosyan L., Stepanenko K., Guseynov F. (2018). Modern Educational Domain: Bilingualism and Multilingualism in Teaching Foreign Languages. In V. Dislere (Ed.), The Proceedings of the International Scientific Conference Rural Environment. Education. Personality (REEP), 11. Jelgava: LLU TF, 109-117. Retrieved from http://llufb.llu.lv/conference/REEP/2018/Latvia_REEP_2018_proceedings_ISSN2255808X-109-117.pdf

22. Samuels A.J. (2018). Exploring Culturally Responsive Pedagogy: Teachers' Perspectives on Fostering Equitable and Inclusive Classrooms. STRATE Journal, 27(1). Retrieved from https://files.eric.ed.gov/fulltext/EJ1166706.pdf

23. Villegas A.M., Lucas T. (2002). Preparing Culturally Responsive Teachers. Rethinking the Curriculum. Journal of Teacher Education, 53(1), 20-32. Retrieved from https://www.researchgate.net/publication/237699170_Preparing_Culturally_Responsive_Teachers_R ethinking_the_Curriculum

24. Wilson J., Ward C., Fischer R. (2013). Beyond Culture Learning Theory: What Can Personality Tell Us About Cultural Competence? Journal of Cross-Cultural Psychology, 44(6), 900-927. Retrieved from https:/www.researchgate.net/publication/258144424_Beyond_Culture_Learning_Theory_What_Can Personality_Tell_Us_About_Cultural_Competence

25. Żimnyaya I.A. (2000). Pedagogicheskaya Psixologiya (Pedagogical psychology). Moskva: Logos. (in Russian) 